similar manner to black bodies, although they are actually 'grey body' radiators. This being so, the continuous spectrum of a star can be matched in colour with black body radiation corresponding to some temperature, and this temperature is called the 'colour temperature' of the star.

The light from a star consists of radiation from its surface and, to some extent, radiation from its lower layers which has only been partly absorbed on its way to the surface. Theoretical investigation shows that, subject to certain hypotheses, the colour temperature of a star is about twenty-five per cent greater than the actual temperature of the surface. A comparison is made between the light emitted by the star and a laboratory source the colour tempera. ture of which is known, and it is necessary to measure the ratios of the radiations from the star and the laboratory source at two separate wave-lengths. Applying Planck's formula for the ratio of the radiations from the latter at the two wave-lengths, the measured ratios make it possible to derive the ratio of the radiations from the star at these wavelengths. We then have the data to give the colour temperature.

For measurement, the spectra from the star and laboratory source are photographed on the same plate and the photo-chemical properties of the emulsion are utilised, since there is a relationship between the optical density or degree of blackening of the negative and the amount of light which caused it. By an additional series of exposures of the plate to sources of light the relative intensities of which are known, spectral images are formed which enable a calibration curve to be made for any particular wavelength, and from this, differences in optical density can be converted into ratios of light. The data obtained yield a quantity known as the 'colour function', which is related to colour temperature by a formula derived from Planck's formula, and thence the colour temperature of the star is obtained.

Star light is reddened in passing through the earth's atmosphere and the observations have to be corrected for this effect. Use is made of a system of stars the differences of colour function of which have been measured by a set of comparisons in pairs at equal altitudes above the horizon. Pairs of stars chosen from this system are now photographed at unequal altitudes, and each such comparison yields a quantity, part of which is due to difference in colour function and part to the atmospheric effect. As the difference of colour functions has been already obtained, atmospheric reddening can be determined and applied to comparisons between stars and the laboratory source used for comparison.

Well-determined colour temperatures for a number of stars are now available as a result of the work at different observatories, and in the study of the rela. tionship between temperature and other effects a striking correlation of temperature with spectral type has been found.

\title{
Reorganisation of the University of Durham
}

$\mathrm{T}^{\mathrm{H}}$ HE University of Durham entered upon the second century of its existence three years ago with prospects somewhat clouded by controversies relating to medical education. The Royal Commission appointed in March 1934 to report on the University's organisation and work found the constitution of the College of Medicine, which, together with Armstrong College, forms the Newcastle Division of the University, and also the University statutes, to be radically unsound in many respects and more particularly in their failure to confer on the University any control over the fate of one of its own professors.

The recommendations of the Commission, embodied in the report just published (London : H.M. Stationery Office, Cmd. 4815. 1s.6d. net) provide for the reconstitution of the Newcastle Division as a single unit by the amalgamation of its two colleges under a head, to be appointed, in the first instance, by the Crown. For the guidance of the organisation and development of medical education and the maintenance of close relations between the College and the associated hospitals, responsibility would be vested in a dean of medicine, to be ex-officio a member of the Court and Senate of the University and of the Couneil and Academic Board of the College and chairman of the Board of the Faculty of Medicine and of the Medical Studies Committee of the Academic Board.

Of the two schools of thought with regard to the place and treatment of chemistry and biology regarded as part of the medical curriculum proper, the Commission has ranged itself emphatically on the side of the champions of the closest collaboration. between the medical departments and the science departments in a university, the precise allocation of the teaching of the various frontier subjects being left to be determined in the light of the whole of the teaching power which is available, rather than by mere departmental considerations: granted the desirability of relating the teaching of chemistry and biology to human physiology and anatomy and to medical problems generally, the one thing to avoid, in the interests of the teachers themselves as well as of the students, is a divorce of this specialised teaching from the university departments devoted to chemistry and biology.

Medical education in Newcastle has been somewhat hampered for many years by inadequate premises. Land for new buildings adjoining Armstrong College and opposite the Royal Victoria Infirmary has been acquired, however, and an extensive scheme involving the sale of the present site of the College of Medicine has for some time been under consideration. Among the recommendations of the Royal Commission on the affairs of the University is one for the constitution of a temporary board of five persons, four appointed by the College of Medicine and one appointed by Armstrong College, to sell the existing premises and generally to arrange for the finance of the new building, to control the proceeds of sale and the greater part of the capital funds at present vested in the College, to assume control of the new site and supervise the erection of the new buildings and ultimately to transfer the premises together with any funds in its hands to the proposed new University College to be formed by amalgamation of Armstrong College with the College of Medicine. A time limit not exceeding seven years would be fixed within which the Board would have to complete its activities.

The Durham Observatory, which was opened in 1841, is at present vested in the Council of the Durham Colleges, and is managed by a large body of curators, of whom some are teachers in Newcastle. 
In the general debacle which overtook the teaching of science in the University of Durham in the eighteensixties, the study of astronomy survived and at times the astronomical work has been of considerable importance. A seismograph was installed in 1929. Among the Royal Commission's recommendations for the future government of the University is a proposal that the Observatory should be transferred from the Council of the Durham Colleges to the University. It is pointed out that, there being science departments in both the Durham and the Newcastle Divisions, the work of the Observatory should be regarded as a central university activity.

\section{University and Educational Intelligence}

Cambridge.-The General Board has issued a report on the future organisation of teaching and research in erystallography. The following recommendations are made. (1) The Crystallographic Laboratory shall be under the control of the Cavendish professor of experimental physics. (2) All teaching of crystallography for Part I of the Natural Sciences Tripos shall be given in the Department of Mineralogy and Petrology. All teaching of crystallography for Part II of the Natural Sciences Tripos shall be given in the Crystallographic Laboratory. (3) The research facilities of the Crystallographic Laboratory shall be available for use by the staff of the Department of Mineralogy and Petrology and the research facilities of the Department of Mineralogy and Petrology shall be available in a similar manner for use by the staff of the Crystallographic Laboratory. (4) There shall be an assistant director of research in crystallography who shall be responsible to the Cavendish professor for advanced teaching and direction of research in crystallography. (5) There shall be an assistant in experimental research in crystallography whose duty shall be to help the assistant director of research. He shall be appointed by the Cavendish professor, subject to confirmation by the General Board. It is recommended further that Mr. J. D. Bernal, of Emmanuel College, be appointed assistant director of research in crystallography from October 1, 1934, with a pensionable stipend of $£ 500$ a year.

OXFORD.--The contributions to science by the early members of Wadham College formed the subject of a public lecture in the Hall of the College on March 2. The speaker, Dr. R. T. Gunther, stated that but for a most lamentable accident the lecture would have been delivered by the late Dr. F. A. Dixey, whose unrivalled knowledge of the connexion of the early fellows of the College with the foundation of the Royal Society had delighted many audiences in that hall. Portraits of John Wilkins, Sprat, Seth Ward and Wren hang on its walls. Sydenham and Mayow were among its members. Less well-known was the botanical work of Walter Stonehouse (1597-1655) and of Richard Warner (1713-75).

THe Royal University of Pisa is offering a research scholarship for the year 1935-36 under the Galileo Galilei Foundation. The scholarship is open to all and, if a candidate is not Italian, he will be expected to carry out scientific research in an Italian institute during the tenure of the scholarship. Further information can be obtained from the Rector of the University of Pisa.
The first Regional British Isles Conference of the New Education Fellowship will be held at the University of St. Andrews on August 13-22, under the presidency of Dr. A. D. Lindsay, Master of Balliol College, Oxford. The theme of the Conference will be "Education and Leisure: How to Create a Democratic Culture". Two problems will be dis. cussed, namely, education for leisure at schools and the provision of facilities and training for adolescents and adults so that they may be able to make use of their leisure after school life is over. The subject of Dr. Lindsay's address will be "Unemployment and Education". Further information can be obtained from the New Education. Fellowship, 29 Tavistock Square, London, W.C.1.

\section{Science News a Century Ago}

\section{A Description of Upper California}

At a meeting of the Royal Geographical Society on March 9, 1835, a communication was read from Dr. Coulter describing Upper California, in which he had resided for two years. The only portion of the country which was settled was mainly along the coast, the chief settlers being the Catholic missionaries, who sought to collect around their stations an Indian population, whom they taught, in a rude way, to till the ground and rear domestic cattle, while they compelled them to conform to their religious observances. The great article of produce was black cattle. In 1827 the missions possessed 210,000 branded cattle, and it was supposed not less than 300,000 unbranded. The number of white inbabitants in Upper California was estimated by Dr. Coulter at 6,000 , and they were rapidly increasing, while the Indian population was decreasing. The prospects for settlers in the north were good, the district being highly fertile, well wooded and watered. The Tuli Lakes, although shallow in the dry season, furnished good facilities for the transport of wood, hides, etc. Gold had been found in a stream falling into the Southern Tuli.

\section{Colliery Explosion near Wigan}

According to the Annual Register for 1835, an explosion of firedamp in a coal mine near Wigan on March 9, 1835, caused the death of three women working in the mine. There were only six persons working in the pit, which was a small one, but the pit was known always to contain a great quantity of inflammable gas. Owing to this, a piece of cloth had been placed at the bottom of the pit to assist in ventilating it, but on the day of the accident this was not in place. On a workman, Peter Tabernier, going into the colliery with a naked light, he noticed symptoms of an approaching explosion and hastened to get out of the pit, calling the others also to do so. Unfortunately, before they could get out, the explosion took place, burning two men badly, and killing another man and three sisters aged respectively nineteen, seventeen and fourteen years. "Had Tabernier," said the Annual Register, "taken the precaution of using Davy's safety lamp, instead of approaching with an unguarded light, which as soon as it approached, set fire to the explosive fluid, this accident in ail probability would not have happened. $\mathrm{He}$ had one of the lamps at home but out of repair, and through the extreme poverty to which he was reduced, he could not afford to get it repaired." 